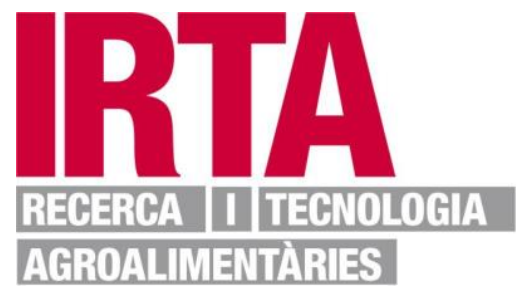

This document is the Accepted Manuscript version of a Published Work that appeared in final form in Analytical Chemistry, copyright $@$ American Chemical Society after peer review and technical editing by the publisher. To access the final edited and published work see https://pubs.acs.org/doi/abs/10.1021/acs.analchem.9b04499

Document downloaded from:

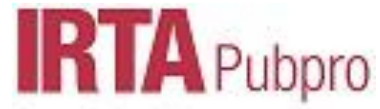

Open dgital archive 


\title{
Addressing the analytical challenges for the detection of ciguatoxins using an electrochemical biosensor
}

\author{
Sandra Leonardo ${ }^{1}$, Greta Gaiani ${ }^{1}$, Takeshi Tsumuraya ${ }^{2}$, Masahiro Hirama ${ }^{2}$, Jean Turquet $^{3}$, Núria Sa- \\ gristà $^{1}$, Maria Rambla-Alegre ${ }^{1}$, Cintia Flores ${ }^{4}$, Josep Caixach ${ }^{4}$, Jorge Diogène ${ }^{1}$, Ciara K. O’Sullivan ${ }^{5,6}$, \\ Carles Alcaraz ${ }^{1}$, Mònica Campàs ${ }^{1 *}$
}

${ }^{1}$ IRTA, Ctra. Poble Nou km 5.5, 43540 Sant Carles de la Ràpita, Spain

${ }^{2}$ Department of Biological Sciences, Graduate School of Science, Osaka Prefecture University, Osaka 599-8570, Japan

${ }^{3}$ Citeb, C/o CYROI, 2 Rue Maxime Rivière, 97490 Sainte Clotilde, La Réunion, France

${ }^{4}$ Mass Spectrometry Laboratory/Organic Pollutants, IDAEA-CSIC, C. Jordi Girona 18, 08034 Barcelona, Spain

${ }^{5}$ Departament d'Enginyeria Química, URV, Av. Països Catalans 26, 43007 Tarragona, Spain

${ }^{6}$ ICREA, Pg. Lluís Companys 23, 08010 Barcelona, Spain

\begin{abstract}
The importance of ciguatoxins (CTXs) in seafood safety and their emerging occurrence in locations far away from tropical areas highlight the need for simple and low-cost methods for the sensitive and rapid detection of these potent marine toxins to protect seafood consumers. Herein, an electrochemical immunosensor for the detection of CTXs is presented. A sandwich configuration is proposed, using magnetic beads (MBs) as immobilisation supports for two capture antibodies, with their combination facilitating the detection of CTX1B, CTX3C, 54-deoxyCTX1B and 51-hydroxyCTX3C. PolyHRP-streptavidin is used for the detection of the biotinylated detector antibody. Experimental conditions are first optimised using colorimetry, and these conditions are subsequently used for electrochemical detection on electrode arrays. Limits of detection at the pg/mL level are achieved for CTX1B and 51-hydroxyCTX3C. The applicability of the immunosensor to the analysis of fish samples is demonstrated, attaining detection of CTX1B at contents as low as $0.01 \mu \mathrm{g} / \mathrm{kg}$, and providing results in correlation with those obtained using mouse bioassay (MBA) and cell-based assay (CBA), as well as liquid chromatography coupled to high-resolution mass spectrometry (LC-ESI-HRMS). This user-friendly bioanalytical tool for the rapid detection of CTXs can be used to mitigate ciguatera risk and contribute to the protection of consumer health.
\end{abstract}

Ciguatera fish poisoning (CFP) is the most common and one of the most relevant seafood-borne diseases worldwide, affecting from 10,000 to 500,000 people per year, and probably even more due to underdiagnosis and underreporting. ${ }^{1} \mathrm{CFP}$ is characterised by severe neurological, gastrointestinal and cardiovascular disorders that usually abate within a few days or weeks but can persist for months or years. ${ }^{2}$ CFP is caused by the ingestion of fish contaminated with ciguatoxins (CTXs), potent lipophilic marine toxins with complex chemical structures ${ }^{3}$ produced by microalgae of the genus Gambierdiscus ${ }^{4-7}$ and $\mathrm{Fu}_{\text {- }}$ kuyoa $^{6,8}$ that accumulate in fish through the food webs. There are several types of CTXs depending on their chemical structure. CTXs have been historically classified according to their geographical origin into Pacific $(\mathrm{P})^{9-11}$, Caribbean $(\mathrm{C})^{12-13}$ and Indic (I) ${ }^{14-15}$ CTXs. However, CTXs are emerging in places not previously expected according to their latitude, particularly in Europe. In recent years, several species of Gambierdiscus have been found in the Canary Islands, ${ }^{16-20}$ where several CFP outbreaks have also occurred. ${ }^{21-23}$ CTXs have also been detected in fish from other areas of the Macaronesia, i.e. Azores and Madeira archipelagos (Portugal). ${ }^{24-25}$ Gambierdiscus sp. ${ }^{26}$ G. australes $^{27}$ and $F$. paulensis ${ }^{28}$ have been recorded in the Mediterranean Sea.

To protect consumer health, the United States Food and Drug Administration (US FDA) proposed guidance levels of $\leq 0.01$ $\mu \mathrm{g} / \mathrm{kg}$ of CTX1B equivalent toxicity in fish. ${ }^{29}$ In Europe, although the legislation requires that no fish products containing CTXs are placed on the market (Regulation (EC) No. $853 / 2004$ ), no regulatory limits have been established and no details regarding the analytical methodology that should be employed have been provided. Other parts of the world, such as Australia or New Zealand, provide guidelines on the susceptible fish species and the local areas where fish may be toxic ${ }^{30}$ and, in Japan, the sale of barracuda and other fish species associated with CFP is banned, but no specific regulations for CTXs are provided. ${ }^{31-32}$

The mouse bioassay (MBA) has been the most widely used method to detect CTXs. Due to its insufficient detection capability and ethical concerns, other methods have been developed, including high-performance liquid chromatography coupled with mass spectrometry, cell-based assays (CBAs) and receptor binding assays. ${ }^{33}$ The analysis of CTXs in fish is hampered by the fact that certified reference calibrants and materials are not readily available. This issue together with the chemical complexity of CTXs have hindered the production of specific antibodies. Hokama and co-workers produced anti-CTX polyclonal antibodies (pAbs) that were used for the development of some immunoassays ${ }^{34}$ and two immunostrip tests, marketed as CiguaCheck $^{35-36}$ and Ciguatect kit. ${ }^{37}$ These antibodies showed high cross-reactivity with another marine toxin, okadaic acid, and the performance of the tests was very controversial as both false positive and false negative results were obtained. ${ }^{38-40}$ In fact, fish determined as positive in Israel, ${ }^{41}$ the first and only report of ciguateric fish in the Mediterranean, had been analysed using only the Cigua-Check kit, and confirmation of CTXs in fish from this area is in fact still pending. On the other hand, synthetic haptens as an alternative to natural CTXs were exploited for the production of monoclonal antibodies (mAbs) that were subsequently used in immunoassays and observed to have high enough specificity and sensitivity. ${ }^{42-48}$ Taking into account these successful results and with the aim to move towards compact and automated devices, the development of an electrochemical immunosensor for the detection of CTXs is undertaken for the first time. 
In this work, three different mAbs (3G8, $10 \mathrm{C} 9$ and 8H4) that specifically bind to one of the wings of the four principal congeners of CTXs (CTX1B, CTX3C, 51-hydroxyCTX3C and 54deoxyCTX1B) are used to develop a sandwich immunosensor. Magnetic beads (MBs) are exploited as a support to provide an enlarged surface area for the immobilisation of mAbs, to shorten the analysis time and to minimise matrix effects. The applicability of the immunosensor to the analysis of fish is successfully demonstrated, enabling the discrimination between contaminated and non-contaminated samples and the detection of CTX1B contents at $0.01 \mu \mathrm{g} / \mathrm{kg}$. Liquid chromatography coupled to electrospray ionisation high-resolution mass spectrometry (LC-ESI-HRMS) analysis confirmed the presence of CTX1B in fish. The availability of this user-friendly bioanalytical tool for the rapid detection of CTXs can mitigate the risk of ciguatera and contribute to consumer health protection.

\section{EXPERIMENTAL SECTION}

Reagents and solutions. Dynabeads M-270 Carboxylic Acid ( 2 x $10^{9}$ beads $/ \mathrm{mL}$ ) were supplied by Invitrogen (Life Technologies, S.A., Alcobendas, Spain). Potassium phosphate monobasic, potassium phosphate dibasic, potassium chloride, 4-morpholineethanesulfonic acid (MES) hydrate, N-(3-dimethylaminopropyl)-N'-ethylcarbodiimide hydrochloride (EDC), Nhydroxysuccinimide (NHS), Tween ${ }^{\circledR}-20$, bovine serum album (BSA), anti-mouse IgG (whole molecule)-horseradish peroxidase antibody produced in rabbit (IgG-HRP), and 3,3',5,5' -tetramethylbenzidine (TMB) liquid substrate were purchased from Sigma-Aldrich (Tres Cantos, Spain). PolyHRP-streptavidin was obtained from Thermo Fisher (Barcelona, Spain). Milli-Q water (Millipore, Bedford, USA) was used to prepare all solutions. For the extractions, acetone and diethyl ether were obtained from Chem-lab (Zedelgem, Belgium), ethanol from J. T. Baker (Madrid, Spain), and methanol and $n$-hexane from Honeywell (Barcelona, Spain). For LC-ESI-HRMS, HPLC-MS grade acetonitrile and water were supplied by Chem-lab (Zedelgem, Belgium), and ammonium formate and formic acid by Sigma-Aldrich (Tres Cantos, Spain). CTX1B standard solution was obtained from Prof. Richard J. Lewis (The Queensland University, Australia) and calibrated (correction factor of 90\%) in relation to the NMR-quantified CTX1B standard solution from Prof. Takeshi Yasumoto (Japan Food Research Laboratories, Japan). NMR-quantified 51-hydroxyCTX3C standard solution was kindly provided by Prof. Takeshi Yasumoto. 3G8, $10 \mathrm{C} 9$ and $8 \mathrm{H} 4 \mathrm{mAbs}$ had been prepared by immunising mice with keyhole limpet hemocyanin (KLH) conjugates of rationally designed synthetic haptens (Oguri et al., 1999, 2003; Nagumo et al., 2001, 2004; Tsumuraya et al., 2006, 2010, 2012, 2014). Biotin labelling of the $8 \mathrm{H} 4 \mathrm{mAb}$ was performed with the EZ-Link ${ }^{\mathrm{TM}}$ NHS-PEG4 Biotinylation Kit from Thermo Fisher (Barcelona, Spain) following the manufacturer's instructions. Unreacted NHS-PEG4-Biotin was removed using Zeba Spin Desalting Columns (7 kDa MWCO, 2mL) included in the kit.

Equipment. Magnetic separation was performed using a MagneSphere Technology Magnetic Separation Stand (for twelve 0.5-mL or 1.5-mL tubes) and a PolyATtract System 1000 Magnetic Separation Stand (for one 15-mL tube) from Promega Corporation (Madison, WI, USA). Colorimetric measurements were performed with a Microplate Reader KC4 from BIO-TEK Instruments, Inc. (Vermont, USA). Gen5 software was used to collect and evaluate data. Screen-printed electrode arrays (DRP-8x110), a boxed connector (DRP-CAST8X) and a magnetic support (DRP-MAGNET8X) were purchased from Dropsens S.L. (Oviedo, Spain). The arrays consist of 8 carbon working electrodes of $2.5 \mathrm{~mm}$ in diameter, each with its own counter and silver reference electrodes. Amperometric measurements were performed with a PalmSens potentiostat connected to an 8-channel multiplexer (MUX8) (Houte, The Netherlands). PalmSens PC software was used to collect and evaluate data.

Fish samples and extraction. Sampling was performed at various locations of the Indian Ocean close to Réunion and Maurice Islands. Variola louti $(\mathrm{N}=9)$, Lutjanus bohar $(\mathrm{N}=6)$ and Thyrsitoides marleyi $(\mathrm{N}=1)$ specimens were collected. Fishing dates and sites are summarised in Table 1. Fish samples were processed as previously described ${ }^{49}$ Briefly, $10 \mathrm{~g}$ of fish flesh homogenate were heated at $70{ }^{\circ} \mathrm{C}$ for $15 \mathrm{~min}$ in a water bath. Subsequently, $20 \mathrm{~mL}$ of acetone was added and the sample mixture was homogenised with an Ultra-turrax blender at $17500 \mathrm{xg}$ for $5 \mathrm{~min}$. The sample mixture was centrifuged at $3000 \mathrm{xg}$ for 10 min to obtain the supernatant. The pellet was re-extracted with acetone, and supernatants were pooled, filtered with 0.45 $\mu \mathrm{m}$ nylon filters and evaporated at $55^{\circ} \mathrm{C}$. The dried extract was dissolved in $5 \mathrm{~mL}$ of methanol:water $(9: 1, v: v)$ and partitioned twice with $5 \mathrm{~mL}$ of $n$-hexane, and the $n$-hexane phases were discarded. The aqueous methanol solution was dried by rotary evaporation. The residue was dissolved in $5 \mathrm{~mL}$ of ethanol:water $(1: 3, v: v)$ and partitioned twice with $5 \mathrm{~mL}$ of diethyl ether. Diethyl ether fractions were pooled and dried. The residue was re-suspended in $4 \mathrm{~mL}$ of methanol and kept at $-20{ }^{\circ} \mathrm{C}$ until analysed. For calculation purposes, $1 \mathrm{~mL}$ of extract contains $2.5 \mathrm{~g}$ equivalents of fish flesh.

Conjugation of the capture mAbs to MBs. 3G8 and 10C9 mAb-MB conjugates were prepared as follows: (1) $8 \mu \mathrm{L}$ of $\mathrm{MB}$ suspension were transferred to a tube and washed twice with $500 \mu \mathrm{L}$ of MES (25 mM MES, pH 5.0) with vigorous mixing; for the washing steps, the tube was placed on the magnetic separation stand and the washing solution was removed; (2) $40 \mu \mathrm{L}$ of $50 \mathrm{mg} / \mathrm{mL}$ EDC and $40 \mu \mathrm{L}$ of $50 \mathrm{mg} / \mathrm{mL}$ NHS were added and incubated for $30 \mathrm{~min}$; (3) the activated MBs were washed twice with MES; (4) $80 \mu \mathrm{L}$ of $3 \mathrm{G} 8$ or $10 \mathrm{C} 9 \mathrm{mAb}$ in MES (from $1 / 50$ to $1 / 3200$ dilution for protocol optimisation and $1 / 50$ dilution for the final assay) were added and incubated for 1 hour; (5) the mAb-MB conjugate was washed three times with PBSTween (0.1 M PBS, $0.05 \% v / v$ Tween $\left.{ }^{\circledR}-20, \mathrm{pH} 7.2\right)$ and re-suspended in $80 \mu \mathrm{L}$ of the same buffer. All incubations were performed at room temperature and with slow tilt rotation. When the amounts of MB varied, the volumes were adjusted proportionally. To confirm the conjugation of the mAbs to the MBs and optimise the dilution to be used, $25 \mu \mathrm{L}$ of mAb-MB conjugate were transferred to a new tube and incubated with $250 \mu \mathrm{L}$

of anti-mouse IgG-HRP in PBS-Tween containing 1\% $w / v$ BSA (PBS-Tween-BSA) (1/1000 dilution) for $30 \mathrm{~min}$, and after two washing steps with PBS-Tween, $20 \mu \mathrm{L}$ of the immunoconjugate were transferred to a new tube, the supernatant was removed, and $125 \mu \mathrm{L}$ of TMB were added, followed by a 5 min incubation. Finally, the tube was placed on the magnetic separation stand and $100 \mu \mathrm{L}$ taken for absorbance reading at $620 \mathrm{~nm}$. 
Table 1. Fish data and CTX1B equivalent contents (pg/g) ( \pm standard deviation) obtained in their analysis using MBA, CBA, colorimetric immunoassay and electrochemical biosensor.

\begin{tabular}{|c|c|c|c|c|c|c|}
\hline Species & Fishing date & Fishing site & MBA & CBA & Immunoassay & Immunosensor \\
\hline Variola louti & January 2013 & Saint-Gilles, Réunion & nd & nd & nd & nd \\
\hline Variola louti & March 2013 & Saint-Gilles, Réunion & nd & nd & nd & nd \\
\hline Variola louti & March 2013 & Saint-Gilles, Réunion & nd & nd & nd & nd \\
\hline Variola louti & March 2013 & Saint-Gilles, Réunion & nd & nd & nd & nd \\
\hline Variola louti & April 2013 & Saint-Gilles, Réunion & nd & nd & nd & nd \\
\hline Variola louti & July 2003 & $\begin{array}{c}\text { La Pérouse Seamount, } \\
\text { Réunion }\end{array}$ & ++ & $9.74 \pm 0.47$ & $33.44 \pm 2.04$ & $26.14 \pm 1.56$ \\
\hline Variola louti & April 2004 & $\begin{array}{c}\text { La Pérouse Seamount, } \\
\text { Réunion }\end{array}$ & ++ & $81.66 \pm 9.77$ & $45.81 \pm 13.99$ & $44.40 \pm 20.37$ \\
\hline Variola louti & January 2003 & $\begin{array}{c}\text { La Pérouse Seamount, } \\
\text { Réunion }\end{array}$ & ++ & $580.06 \pm 86.36$ & $107.31 \pm 5.18$ & $97.41 \pm 34.36$ \\
\hline Variola louti†* & March 2015 & Maurice & +++ & $2104.00 \pm 224.43$ & $279.77 \pm 3.69$ & $247.85 \pm 35.56$ \\
\hline Lutjanus bohar & September 2002 & $\begin{array}{c}\text { La Pérouse Seamount, } \\
\text { Réunion }\end{array}$ & ++ & $21.75 \pm 0.30$ & $9.19 \pm 0.51$ & $7.36 \pm 0.64$ \\
\hline Lutjanus bohar & August 2003 & $\begin{array}{c}\text { La Pérouse Seamount, } \\
\text { Réunion }\end{array}$ & ++ & $440.68 \pm 20.94$ & $9.02 \pm 1.01$ & $7.72 \pm 0.90$ \\
\hline Lutjanus bohar & August 2003 & $\begin{array}{c}\text { La Pérouse Seamount, } \\
\text { Réunion }\end{array}$ & ++ & $552.70 \pm 83.91$ & $22.76 \pm 0.54$ & $18.92 \pm 5.41$ \\
\hline Lutjanus bohar & December 2003 & $\begin{array}{l}\text { La Pérouse Seamount, } \\
\text { Réunion }\end{array}$ & ++ & $506.47 \pm 86.36$ & $27.12 \pm 0.92$ & $27.73 \pm 8.79$ \\
\hline Lutjanus bohar* & February 2003 & $\begin{array}{l}\text { La Pérouse Seamount, } \\
\text { Réunion }\end{array}$ & ++ & $1296.73 \pm 181.60$ & $149.46 \pm 8.21$ & $134.66 \pm 32.8$ \\
\hline Lutjanus bohar & January 2002 & $\begin{array}{l}\text { La Pérouse Seamount, } \\
\text { Réunion }\end{array}$ & +++ & $2481.03 \pm 727.47$ & $142.46 \pm 2.51$ & $147.04 \pm 28.44$ \\
\hline Thyrsitoides marleyi $\dagger^{*}$ & June 2015 & Saint-Paul, Réunion & +++ & $600.48 \pm 68.86$ & $88.21 \pm 9.50$ & $78.12 \pm 34.11$ \\
\hline
\end{tabular}

$\dagger$ Fish individuals involved in a poisoning case

* Fish individuals analysed by LC-ESI-HRMS

nd: not detected; ++: intermediate toxicity; +++: strong toxicity

Colorimetric immunoassay and electrochemical immunosensor. Sandwich immunoassays were performed in 0.5 $\mathrm{mL}$ tubes following this protocol: (1) $150 \mu \mathrm{L}$ of mAb-MB conjugates ( $75 \mu \mathrm{L}$ of each mAb-MB conjugate) were exposed to 75 $\mu \mathrm{L}$ of CTX1B or 51-hydroxyCTX3C standard solution (congeners chosen as model CTXs) or fish extract (previously evaporated and re-suspended in PBS-Tween) for $30 \mathrm{~min}$; (2) after three washing steps with PBS-Tween, a blocking step was performed with PBS-Tween-BSA (PBS-Tween containing 2\% $\mathrm{w} / \mathrm{v}$ $\mathrm{BSA}$ ) for $30 \mathrm{~min}$; (3) the conjugates were washed three times with PBS-Tween and incubated with $75 \mu \mathrm{L}$ of biotin-8H4 mAb in PBS-Tween-BSA (from 1/50 to $1 / 4000$ dilution for protocol optimisation and 1/2000 dilution for the final assay) for $30 \mathrm{~min}$; (4) three washing steps were performed with PBS-Tween and $75 \mu \mathrm{L}$ of polyHRP-streptavidin in PBS-Tween-BSA (from $1 / 500$ to $1 / 5000$ dilution for protocol optimisation and $1 / 1000$ dilution for the final assay) were added and incubated for 30 min; (6) finally, three washing steps were performed in PBSTween and the content of each tube was re-suspended in $75 \mu \mathrm{L}$ of the same buffer. All incubations were performed at room temperature and with slow tilt rotation. When the amounts of
MB varied, the volumes were adjusted proportionally. Subsequent steps differed slightly between the immunoassay and the immunosensor as described below. For the colorimetric immunoassay: (7) $10 \mu \mathrm{L}$ of immunocomplexes were transferred to a new tube and the supernatant was removed; (8) $125 \mu \mathrm{L}$ of TMB were added, followed by a 10 minute incubation; (9) tubes were placed on the magnetic separation stand and $100 \mu \mathrm{L}$ of solution were taken for absorbance reading at $620 \mathrm{~nm}$. Measurements were performed in duplicate or triplicate. For the electrochemical immunosensor: (7) $10 \mu \mathrm{L}$ of immunocomplexes were placed on each working electrode of the 8-electrode array with a magnetic support on the back, the magnetic immunocomplex was captured and the supernatant was removed; (8) $10 \mu \mathrm{L}$ of TMB were then added, followed by a 2 min incubation; (9) the TMB reduction current was measured using amperometry, applying $-0.2 \mathrm{~V}(v s . \mathrm{Ag}$ ) for $5 \mathrm{~s}$. Measurements were performed in triplicate or quadruplicate.

Mouse bioassay. The protocol was based on a standard method developed by ANSES (CATNAT-10). Fish extracts were solubilised in Tween-60 1-5\% v/v saline solution, and then injected into three mice (male, OF1; $20 \pm 2 \mathrm{~g}$ ) by intraperitoneal (i.p.) 
route. The mice were observed continuously during the first $2 \mathrm{~h}$ and then monitored regularly up to $24 \mathrm{~h}$ after injection. The interpretation of the results was based on the time-to-death and symptoms (profuse diarrhoea, piloerection, respiratory disorders, dyspnoea and transient pre-erectional cyanosis of the penis, which can lead to priapism).

Cell-based assay. The CBA was performed as previously described ${ }^{50}$ Briefly, neuro-2a (N2a) cells (ATCC, CCL131) were seeded in a 96-well microplate in $200 \mathrm{~mL}$ of RPMI medium containing 5\% $v / v$ fetal bovine serum (RPMI-FBS) at 42,500 cells per well and incubated at $37{ }^{\circ} \mathrm{C}$ in a $5 \% \mathrm{CO}_{2}$ humid atmosphere for $24 \mathrm{~h}$. Prior to exposure to CTX1B standard solution or fish extract, some N2a cells were pre-treated with ouabain and veratridine at 1 and $0.1 \mathrm{mM}$, respectively. CTX1B standard solution or fish extract were dried, reconstituted in $200 \mathrm{~mL}$ of RPMI-FBS medium, serially diluted, and $10 \mu \mathrm{L}$ were added to the wells with and without ouabain/veratridine pre-treatment. After $24 \mathrm{~h}$, cell viability was measured using the MTT assay. ${ }^{51}$ Measurements were performed in triplicate.

LC-ESI-HRMS analysis. One $V$. louti individual caught in March 2015, one L. bohar individual caught in February 2003 and a T. marleyi individual were analysed by LC-ESI-HRMS. An Orbitrap-Exactive HCD (Thermo Fisher Scientific, Bremen, Germany) mass spectrometer equipped with a heated electrospray source (H-ESI II), a Surveyor MS Plus pump and an Accela Open AS auto-sampler kept at $15{ }^{\circ} \mathrm{C}$ (Thermo Fisher Scientific, San José, California) were used for the LC-ESIHRMS analysis. The chromatographic separation was performed on a Kinetex XB-C18 reversed phase $(100 \mathrm{~mm} \times 2.1$ $\mathrm{mm}, 2.6 \mu \mathrm{m})$ (Phenomenex, Torrance, CA, USA) at a flow rate of $250 \mu \mathrm{L} / \mathrm{min}$. Mobile phase A was water and B was acetonitrile/water (95:5), both containing $2 \mathrm{mM}$ ammonium formate and $0.1 \% \mathrm{v} / \mathrm{v}$ formic acid. The gradient elution program was: $30 \%$ B $1 \mathrm{~min}, 30-40 \%$ B $2 \mathrm{~min}, 40-50 \%$ B $1 \mathrm{~min}, 50-90 \%$ B 5 min, $90 \%$ B $3 \mathrm{~min}$ and return to initial conditions for re-equilibration (11 min $30 \% \mathrm{~B}$ ). A $5-\mu \mathrm{L}$ injection volume was used. The total duration of the method was $25 \mathrm{~min}$. The analysis was carried out in electrospray positive ionisation (H-ESI+). CTX1B was used to optimize the source, transmission and HRMS conditions in positive mode. The final parameters were: spray voltage of $4.0 \mathrm{kV}$, capillary temperature of $275^{\circ} \mathrm{C}$, heater temperature of $300{ }^{\circ} \mathrm{C}$, sheath gas flow rate of $35 \mathrm{psi}$ and auxiliary gas flow rate of 10 (arbitrary units). Capillary voltage of $47.5 \mathrm{~V}$, tube lens voltage of $186 \mathrm{~V}$ and skimmer voltage of 18 $\mathrm{V}$ were used. Nitrogen was employed as sheath, auxiliary and collision gas. The mass range was $m / z$ 400-1500 in full scan acquisition mode. The resolution was 50,000 ( $\mathrm{m} / \mathrm{z}, 200$, FWHM) at a scan rate $2 \mathrm{~Hz}$, the automatic gain control was set as "balanced" (1e6) with a maximum injection time of $250 \mathrm{~ms}$. Data were processed with Xcalibur 2.2 SP1 software (Thermo Fisher Scientific, Bremen, Germany). Automatic identification/quantification was performed. The peaks found were confirmed by the exact mass of $[\mathrm{M}+\mathrm{H}]^{+},\left[\mathrm{M}+\mathrm{NH}_{4}\right]^{+}$and $[\mathrm{M}+\mathrm{Na}]^{+}$diagnostic ions with a mass accuracy of \pm 3 ppm (mass extraction window) and the retention time window. The following restrictive criteria were also used: elements considered were restricted in accordance with CTXs molecular formulae and adduct signals [C 55 to $70, \mathrm{H} 64$ to $110, \mathrm{O} 11$ to $25, \mathrm{~N} 0$ to 1 , and cations $(\mathrm{Na}) 0$ to 1 , the isotopic pattern was matched and the charge, the ring double bond equivalents and nitrogen rule were taken into account. Additionally, the monoisotopic pattern ( $\mathrm{M}+1$ ion) of these signals was used to assist in the further confirmation of the toxin identity. The relative ion intensities between $\left[\mathrm{M}+\mathrm{NH}_{4}\right]^{+},[\mathrm{M}+\mathrm{Na}]^{+}$and their $\mathrm{M}+1$ ions were calculated and matched taking into account a tolerance according to the EU Decision 2002/657/EC. An external standard calibration was carried out from 1 to $100 \mathrm{ng} / \mathrm{mL}$ of CTX1B with a limit of detection (LOD) of $0.3 \mathrm{ng} / \mathrm{mL}$. The sum of the areas of $[\mathrm{M}+\mathrm{H}]^{+}+\left[\mathrm{M}+\mathrm{NH}_{4}\right]^{+}+[\mathrm{M}+\mathrm{Na}]^{+}$signals was used for quantification purposes.

\section{RESULTS AND DISCUSSION}

The concept of the immunosensor is schematically depicted in Fig. 1. On one side, two different mouse mAbs, 3G8 mAb able to bind to the left wing of CTX1B and 54-deoxyCTX1B ${ }^{48}$ and 10C9 mAb able to bind to the left wing of CTX3C and 51-hydroxyCTX $3 \mathrm{C},{ }^{46}$ were immobilised separately on MBs and used as capture antibodies. On the other side, $8 \mathrm{H} 4$ mouse $\mathrm{mAb}$, which binds to the right wing of CTX1B, CTX3C, 54-deoxyCTX1B and 51-hydroxyCTX3C, ${ }^{46}$ was biotinylated and used as a detector antibody. Following successive incubations of the magnetic immunocomplexes with the analyte and the biotinylated $8 \mathrm{H} 4 \mathrm{mAb}$, polyHRP-streptavidin was used for signal reporting. Signal amplification was achieved by replacing the conventional HRP-streptavidin by polyHRP-streptavidin, a conjugate that contains a polymer with approximately $20 \mathrm{HRP}$ molecules per streptavidin molecule.

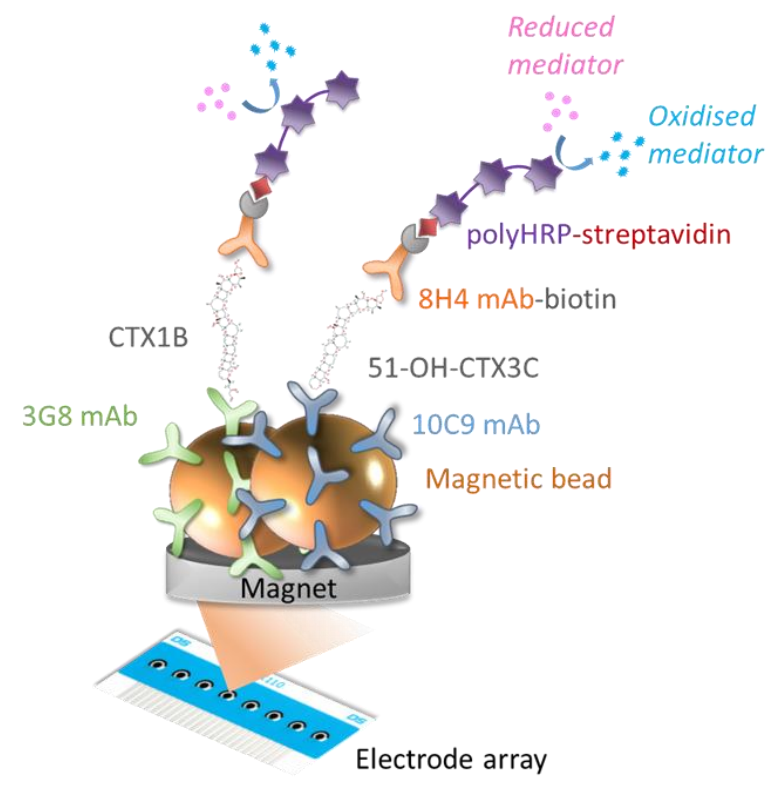

Figure 1. Representation of the electrochemical immunosensor for the detection of CTXs.

Optimisation of the experimental conditions. Capture mAbs were conjugated to carboxylic acid-modified MBs through carbodiimide coupling using EDC-NHS. Several 3G8 mAb dilutions were used to optimise the amount of antibody. Anti-mouse IgG-HRP was used to detect the immobilised antibody. As expected, absorbance values increased with increasing amounts of antibody (Fig. S1). No saturation of the MBs was observed even with the highest antibody concentration tested (1/50 mAb dilution). This dilution was thus selected for further experiments as well as for 10C9 mAb.

The amount of biotinylated $8 \mathrm{H} 4 \mathrm{mAb}$ was optimised using $3 \mathrm{G} 8$ $\mathrm{mAb}$ at $1 / 50$ dilution, CTX1B at 1000 and $0 \mathrm{pg} / \mathrm{mL}$ and polyHRP-streptavidin at 1/1000 dilution. The best signal-to-noise absorbance ratio was achieved with $1 / 2000$ biotinylated $8 \mathrm{H} 4$ 
mAb dilution (Fig. S2), which was selected for further experiments. These results demonstrated the correct performance of the system as well as the successful biotinylation of the $8 \mathrm{H} 4$ $\mathrm{mAb}$, which maintains its affinity for the right wing of CTX1B once biotinylated.

PolyHRP-streptavidin was selected to amplify the signals and its concentration was optimised to achieve the best signal-noise ratio. The $3 \mathrm{G} 8 \mathrm{mAb}-\mathrm{MB}$ conjugates were exposed to $\mathrm{CTX} 1 \mathrm{~B}$ at 100 and $0 \mathrm{pg} / \mathrm{mL}$ and biotinylated $8 \mathrm{H} 4 \mathrm{mAb}$ at $1 / 2000$ dilution, and subsequently incubated with a range of polyHRPstreptavidin dilutions (Fig. S3). Very low non-specific values were observed. In the presence of CTX1B, absorbance values obtained from $1 / 500$ to $1 / 2000$ dilutions did not show significant differences and the signal observed at a 1/5000 dilution was only slightly lower. Although saturation of the response was achieved even with a 1/2000 polyHRP-streptavidin dilution, a 1/1000 dilution was selected for further experiments to ensure polyHRP-streptavidin availability.

Colorimetric characterisation. Using the optimised conditions, the calibration curve for CTX1B was constructed with 10 $\mu \mathrm{L}$ of $3 \mathrm{G} 8 \mathrm{mAb}-\mathrm{MB}$ conjugate (equivalent to $1 \mu \mathrm{L}$ of $\mathrm{MBs}$ ). As expected, a dose-dependent response was observed (Fig. 2A). The calibration curve was blank-subtracted and fitted to a sigmoidal logistic four-parameter equation. The LOD and limit of quantification (LOQ) were calculated using 3 and 10 times the standard deviation of the blank value (no CTX) and were determined to be 3.29 and $17.52 \mathrm{pg} / \mathrm{mL}$, respectively. The calibration curve for 51-hydroxyCTX3C was then constructed using $10 \mu \mathrm{L}$ of 10C9 mAb-MB conjugate. Again, a dose-dependent response was observed, with a slight saturation at high toxin concentrations (Fig. 2B). LOD and LOQ values of 6.17 and 28.31 $\mathrm{pg} / \mathrm{mL}$ were obtained, respectively. These values are lower than those attained with the colorimetric ELISA (LOD of $280 \mathrm{pg} / \mathrm{mL}$ for CTX1B $)^{43}$ but higher than those achieved with the fluorescence ELISA (LODs of 0.16 and $0.10 \mathrm{pg} / \mathrm{mL}$ for CTX1B and 51-hydroxyCTX3C, respectively). ${ }^{47}$

Since the purpose of the immunosensor is to detect as many CTX analogues as possible, both capture antibodies should be able to work together with no interferences from each other. To evaluate this, $10 \mu \mathrm{L}$ of $3 \mathrm{G} 8 \mathrm{mAb}-\mathrm{MB}$ conjugate and $10 \mu \mathrm{L}$ of $10 \mathrm{C} 9 \mathrm{mAb}-\mathrm{MB}$ conjugate were mixed and calibration curves for CTX1B and 51-hydroxyCTX3C were constructed. The presence of twice the amount of MBs did not interfere in the recognition event or the measurement, as no significant differ-
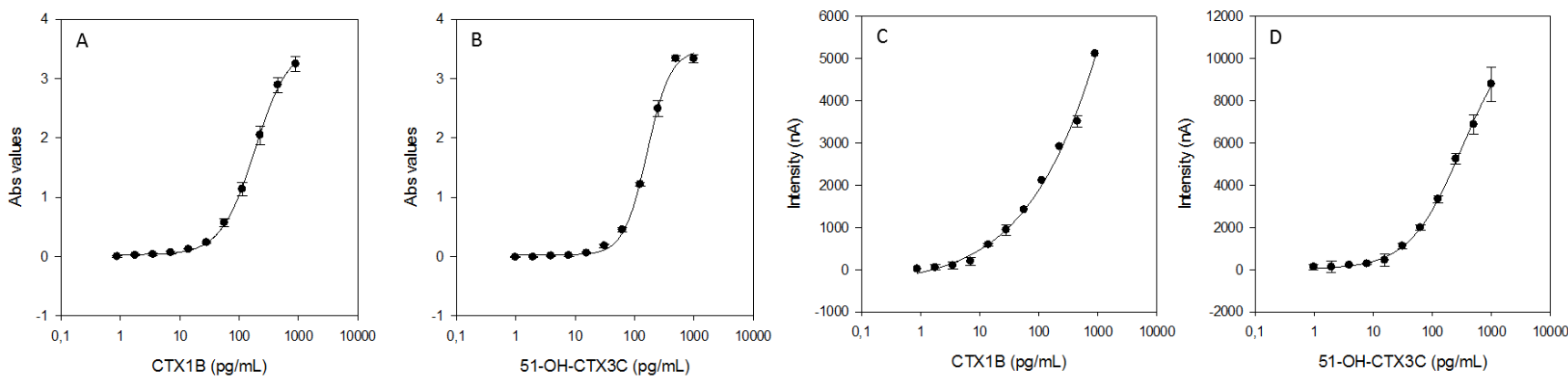

Figure 2. Calibration curves for CTX1B (A and C) and 51-hydroxyCTX3C (B and D) obtained using the colorimetric immunoassay $(\mathrm{A}$ and $\mathrm{B})$ and the electrochemical immunosensor $(\mathrm{C}$ and $\mathrm{D})(\mathrm{N}=3)$. Curves are background-subtracted $(\mathrm{Abs}$ value $=0.089 \pm 0.007$; Intensity $=417 \pm 121 \mathrm{nA})$. 
Fish matrix effects and recovery. The effect of the fish matrix on the responses of the immunoassay and the immunosensor (using both $\mathrm{mAb}-\mathrm{MB}$ conjugates together) was evaluated using a $V$. louti individual that had previously been determined as negative for CTXs by CBA. Absorbance and current intensity values at different extract dilutions were not significantly different from those obtained from the corresponding blanks (no fish extract), even at $2500 \mathrm{mg} / \mathrm{mL}$. This experiment indicates that there is no non-specific adsorption of the capture antibody and/or the polyHRP-streptavidin.

To evaluate if the presence of fish matrix may interfere in the response of the immunoassay and the immunosensor towards CTXs, $100 \mathrm{pg} / \mathrm{mL}$ of CTX1B were spiked into several dilutions of the same $V$. louti extract. Absorbance and current intensity values were compared with those attained with the same amount of CTX1B in buffer. Recovery percentages are shown in Table 2. Although the highest matrix concentration tested had not shown any effect in the previous experiment, CTX detection was affected. As the matrix was diluted, recovery percentages increased reaching nearly $90 \%$. Although the matrix affects CTX quantification, these preliminary recovery values can be used as correction factors to be applied to the CTX quantifications provided by the immunoassay and the immunosensor in the analysis of naturally-contaminated fish.

To evaluate matrix effects between fish individuals, different CTX1B concentrations (from 3 to $100 \mathrm{pg} / \mathrm{mL}$ ) were spiked into two non-contaminated $V$. louti extracts at $2500 \mathrm{mg} / \mathrm{mL}$. According to the ANCOVA test, no significant differences were observed between individuals $(\mathrm{P}=0.65$ for the immunoassay and $\mathrm{P}=0.38$ for the immunosensor). Nonetheless, a more exhaustive analysis (including different fish species, of different size and from different geographical locations) would be required to better define the correction factors.

Table 2. CTX1B recovery values obtained in the analysis of a non-contaminated $V$. louti individual at different matrix concentrations using the colourimetric immunoassay and the electrochemical immunosensor. Values are expressed in percentages $(\%)$ and calculated with reference to the CTX1B spiking level of $100 \mathrm{pg} / \mathrm{mL}$.

\begin{tabular}{|l|r|r|r|r|r|}
\hline & $2500 \mathrm{mg} / \mathrm{mL}$ & $1000 \mathrm{mg} / \mathrm{mL}$ & $500 \mathrm{mg} / \mathrm{mL}$ & $250 \mathrm{mg} / \mathrm{mL}$ & $100 \mathrm{mg} / \mathrm{mL}$ \\
\hline Colorimetry & $65 \pm 3$ & $77 \pm 3$ & $86 \pm 6$ & $88 \pm 4$ & $89 \pm 3$ \\
\hline Electrochemistry & $58 \pm 17$ & $72 \pm 2$ & $76 \pm 14$ & $83 \pm 17$ & $89 \pm 9$ \\
\hline
\end{tabular}

Analysis of fish samples spiked at $0.01 \mu \mathrm{g} / \mathrm{kg}$ CTX1B. Although regulatory limits for CTXs in fish have not yet been issued by official organisations, an important feature of the immunosensor presented herein should be the ability to detect at least CTX1B at $0.01 \mu \mathrm{g} / \mathrm{kg}$. Effective LOQs (eLOQs) were calculated from the calibration curves constructed from the CTX1B spiked $V$. louti extracts at $2500 \mathrm{mg} / \mathrm{mL}$. The eLOQs achieved were $0.01 \mu \mathrm{g} / \mathrm{kg}$ and $0.002 \mu \mathrm{g} / \mathrm{kg}$ for the assay and biosensor, respectively, which are in agreement with the LOQs calculated from the calibration curve in buffer after applying the corresponding correction factors. The precision of the LOQ value was lower than $15 \%$ for both immunosensing tools. Thus, in principle, the developed tools should be able to detect CTX1B at $0.01 \mu \mathrm{g} / \mathrm{kg}$.

To demonstrate this experimentally, the non-contaminated $V$. louti extract was spiked with $25 \mathrm{pg} / \mathrm{mL}$ of CTX1B and analysed at $2500 \mathrm{mg} / \mathrm{mL}$ (which corresponds to $0.01 \mu \mathrm{g} / \mathrm{kg}$ of CTX1B in the fish flesh). Once the absorbance and current intensity values were obtained, the previous recovery values achieved in the analysis of non-contaminated $V$. louti extract at $2500 \mathrm{mg} / \mathrm{mL}$ were used as correction factors and applied to the quantifications of the CTXs. Compared to the spiked level, the recovery values were $99 \%$ and $103 \%$ for the colorimetric immunoassay and the electrochemical biosensor, respectively.

It is important to note that the FDA guidance level is provided in CTX1B equivalent toxicity in fish. This equivalent toxicity is the composite toxicity in relation to CTX1B of the contaminated fish, in which several CTX congeners could be present. Thus, values achieved by the immunosensing tools can be directly compared with US FDA guidance levels when only CTX1B is present in the sample. The immunosensing tools are able to detect CTX3C, 51-hydroxyCTX3C and 54-deox$\mathrm{yCTX} 1 \mathrm{~B}$ in addition to CTX1B, but in an extent not necessarily related to their toxicity. Other non-structurally-related analogues are not detected by the immunosensing tools developed.
Analysis of naturally-contaminated fish samples. Results for the MBA and CTXs contents determined by the immunoassay, the immunosensor and CBA are summarised in Table 1 (Table $\mathrm{S} 1$ shows the raw data before applying the correction factors). Negative and positive individuals as determined by MBA and CBA were also negative and positive by the immunoassay and the immunosensor. An excellent correlation was obtained when comparing the CTX1B equivalent contents obtained using the immunosensor and the immunoassay $(r=0.997 ; P<0.001)$ (Fig. 3A). A good correlation was also observed between the immunosensor and the CBA $(r=0.891 ; P<0.001)$ (Fig. 3B). The higher levels of CTXs obtained using the CBA as compared to the immunoassay and the immunosensor can be explained by the different recognition principles. Whereas the immunochemical tools detect analogues that possess specific wings in their structures (structural immunorecognition), CBA detects analogues that activate voltage-gated sodium channels (toxicological recognition). Thus, CBA could indeed be detecting a higher number of CTXs or could also be detecting other compounds different from CTXs that activate voltage-gated sodium channels. Since the cross-reactivity factors (CRFs) are not necessarily the same as the toxic equivalency factors (TEFs) and many of them are still unknown, quantification between the assays cannot be always be directly compared.

To confirm the presence of CTXs, LC-ESI-HRMS analysis of three naturally-contaminated individuals was performed. The analysis revealed the presence of CTX1B in the $V$. louti individual at 1609 pg/g (Fig. 4, Fig. S4). The presence of other CTX congeners was not confirmed. LC-ESI-HRMS determined around a 6-fold higher CTXs content than that obtained using the developed immunosensing tools. However, no CTXs were detected in the L. bohar and T. marleyi individuals analysed using LC-ESI-HRMS, despite the high toxicities or CTXs contents observed by MBA, CBA and the immunosensing tools. It is important to note that the LOQ of LC-ESI-HRMS is much 
higher than the LOQs attained with the immunosensing tools (i.e. $\sim 400 \mathrm{pg} / \mathrm{g} v s$. $\sim 2-10 \mathrm{pg} / \mathrm{g}$ ). Additionally, whereas LC-ESIHRMS quantifies individual CTX analogues, the immunosensing tools reported here provide a global response of all CTXs detected, being more useful for the detection of CTXs contents in multi-toxin samples where each analogue is at a low concentration.

A higher number of samples should be analysed to provide statistically sound comparisons with LC-ESI-HRMS analysis. Samples with higher CTXs contents and/or pre-concentration and clean-up steps for samples to be analysed by LC-ESIHRMS would be necessary, this work being beyond the scope of this work. Nevertheless, the comparison of the results obtained with the immunosensing tools and CBA shows a good correlation, with each method having advantages and limitations, and their application provide complementary information.
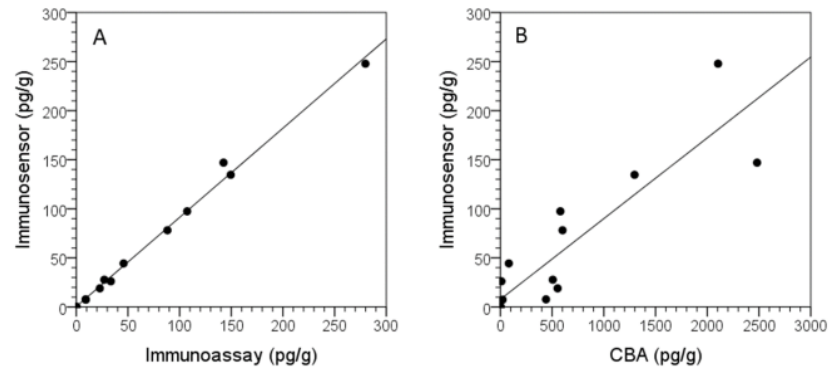

Figure 3. Correlations between CTX1B equivalent contents in fish provided by the electrochemical immunosensor and the colorimetric immunoassay (A) and the electrochemical immunosensor and CBA (B).

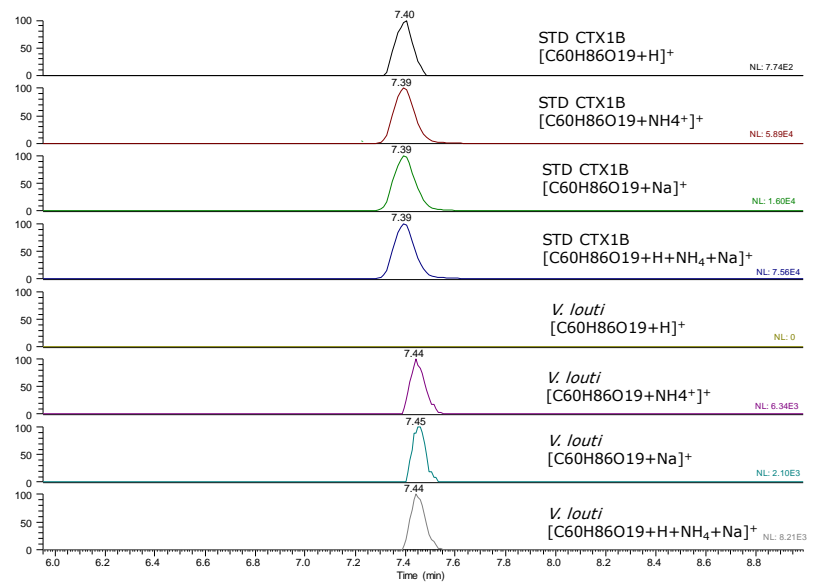

Figure 4. Extract ion chromatogram of CTX1B at $\mathrm{m} / \mathrm{z}$ $1111.5836[\mathrm{M}+\mathrm{H}]^{+}, \quad 1128.6102 \quad\left[\mathrm{M}+\mathrm{NH}_{4}\right]^{+}, \quad 1133.5656$ $[\mathrm{M}+\mathrm{Na}]^{+}$and $\left[\mathrm{M}+\mathrm{H}+\mathrm{NH}_{4}+\mathrm{Na}\right]^{+}$of $\mathrm{CTX} 1 \mathrm{~B}$ standard and $\mathrm{V}$. louti extract.

\section{CONCLUSIONS}

An electrochemical immunosensor for the determination of CTXs in fish has been developed. Taking advantage of the sandwich configuration using magnetic beads as immobilisation supports and polyHRP-streptavidin for signal amplification, together with the benefits provided by electrochemical detection, the biosensor showed an excellent analytical performance in terms of sensitivity and reproducibility for the detection of
CTX1B and 51-hydroxyCTX3C. The immunosensor was successfully applied to the analysis of fish samples, enabling the detection of CTX1B at $0.01 \mu \mathrm{g} / \mathrm{kg}$ and showing a good correlation with CTX levels determined by the CBA. Compared to $\mathrm{CBA}$, the electrochemical immunosensor can tolerate higher matrix concentrations. Whilst the LOD for CTX1B achieved by the immunosensor is slightly higher than using CBA, the effective LOQ is similar. The magneto-immunosensor provides robustness, specificity, simplicity and rapidity in contrast with CBA, which requires working with "live" materials that need maintenance. On the other hand, the immunosensor achieved a LOQ over two orders of magnitude lower than LC-ESI-HRMS, is considerably more cost-effective, and does not require sophisticated instrumentation. Due to its lower cost, ease of operation, portability and lack of need for maintenance, there is no doubt that the electrochemical biosensor can be easily implemented in monitoring and research, clearly addressing the significant challenges faced for the reliable and accurate detection of CTXs at the point-of-need.

\section{ASSOCIATED CONTENT}

\section{Supporting Information}

The Supporting Information is available free of charge on the ACS Publications website. Conjugation of different capture mAb dilutions to MBs. Optimisation of the biotinylated detector mAb dilution. Optimisation of the polyHRP-streptavidin dilution. (PDF)

\section{AUTHOR INFORMATION}

\section{Corresponding Author}

* M. Campàs, IRTA, Ctra. Poble Nou km 5.5, 43540 Sant Carles de la Ràpita, Spain, monica.campas@irta.cat

Notes

The authors declare no competing financial interest.

\section{ACKNOWLEDGMENTS}

The research has received funding from the Ministerio de Economía, Industria y Competitividad (MINECO), the Agencia Estatal de Investigación (AEI) and the Fondo Europeo de Desarrollo Regional (FEDER) through the CIGUASENSING (BIO2017-87946-C2-2-R) project. The authors acknowledge Prof. Takeshi Yasumoto for kindly providing the 51-hydroxyCTX3C standard solution. The authors also acknowledge support from CERCA Programme/Generalitat de Catalunya. G. Gaiani acknowledges IRTA and Universitat Rovira i Virgili for her $\mathrm{PhD}$ grant (2018PMF-PIPF-19).

\section{REFERENCES}

1. Friedman, M.; Fernandez, M.; Backer, L.; Dickey, R.; Bernstein, J.; Schrank, K.; Kibler, S.; Stephan, W.; Gribble, M.; Bienfang, P., An updated review of ciguatera fish poisoning: clinical, epidemiological, environmental, and public health management. Mar. Drugs 2017, 15, 72.

2. Lehane, L.; Lewis, R. J., Ciguatera: recent advances but the risk remains. Int. J. Food Microbiol. 2000, 61, 91-125.

3. Murata, M.; Legrand, A. M.; Ishibashi, Y.; Yasumoto, T., Structures of ciguatoxin and its congener. J. Am. Chem. Soc. 1989, 111, 89298931.

4. Chinain, M.; Darius, H. T.; Ung, A.; Cruchet, P.; Wang, Z.; Ponton, D.; Laurent, D.; Pauillac, S., Growth and toxin production in the ciguatera-causing dinoflagellate Gambierdiscus polynesiensis (Dinophyceae) in culture. Toxicon 2010, 56, 739-750. 
5. Caillaud, A.; de la Iglesia, P.; Barber, E.; Eixarch, H.; MohammadNoor, N.; Yasumoto, T.; Diogene, J., Monitoring of dissolved ciguatoxin and maitotoxin using solid-phase adsorption toxin tracking devices: Application to Gambierdiscus pacificus in culture. Harmful Algae 2011, 10, 433-446.

6. Litaker, R. W.; Holland, W. C.; Hardison, D. R.; Pisapia, F.; Hess, P.; Kibler, S. R.; Tester, P. A., Ciguatoxicity of Gambierdiscus and Fukuyoa species from the Caribbean and Gulf of Mexico. PLoS One 2017, 12, e0185776.

7. Reverté, L.; Toldrà, A.; Andree, K. B.; Fraga, S.; de Falco, G.; Campàs, M.; Diogène, J., Assessment of cytotoxicity in ten strains of Gambierdiscus australes from Macaronesian Islands by neuro-2a cellbased assays. J. Appl. Phycol. 2018, 30, 2447-2461.

8. Lewis, R. J.; Inserra, M.; Vetter, I.; Holland, W. C.; Hardison, D. R.; Tester, P. A.; Litaker, R. W., Rapid extraction and identification of maitotoxin and ciguatoxin-like toxins from Caribbean and Pacific Gambierdiscus using a new functional bioassay. PLoS One 2016, 11, e0160006.

9. Lewis, R. J., The changing face of ciguatera. Toxicon 2001, 39, 97 106.

10. Satake, M.; Fukui, M.; Legrand, A.-M.; Cruchet, P.; Yasumoto, T., Isolation and structures of new ciguatoxin analogs, 2, 3-dihydroxyCTX3C and 51-hydroxyCTX3C, accumulated in tropical reef fish. Tetrahedron Lett. 1998, 39, 1197-1198.

11. Yasumoto, T.; Igarashi, T.; Legrand, A.-M.; Cruchet, P.; Chinain, M.; Fujita, T.; Naoki, H., Structural elucidation of ciguatoxin congeners by fast-atom bombardment tandem mass spectroscopy. J. Am. Chem. Soc. 2000, 122, 4988-4989.

12. Lewis, R.; Vernoux, J.P.; Brereton, M., Structure of Caribbean Ciguatoxin Isolated from Caranx Iatus. J. Am. Chec. Soc. 1998, 120, 24, 5914-5920.

13. Pottier, I.; Vernoux, J. P.; Jones, A.; Lewis, R. J., Characterisation of multiple Caribbean ciguatoxins and congeners in individual specimens of horse-eye jack (Caranx latus) by highperformance liquid chromatography/mass spectrometry. Toxicon 2002, 40, 929-939.

14. Hamilton, B.; Hurbungs, M.; Vernoux, J. P.; Jones, A.; Lewis, R. J., Isolation and characterisation of Indian Ocean ciguatoxin. Toxicon 2002, 40, 685-693.

15. Hamilton, B.; Hurbungs, M.; Jones, A.; Lewis, R. J., Multiple ciguatoxins present in Indian Ocean reef fish. Toxicon 2002, 40, 13471353.

16. Fraga, S., Riobó, P., Diogène, J., Paz, B., \& Franco, J.M., 2004. 11th International Conference on Harmful Algae, Capetown: 115.

17. Fraga, S.; Rodríguez, F., Genus Gambierdiscus in the Canary Islands (NE Atlantic Ocean) with description of Gambierdiscus silvae sp. nov., a new potentially toxic epiphytic benthic dinoflagellate. Protist 2014, 165, 839-853.

18. Fraga, S.; Rodríguez, F.; Caillaud, A.; Diogène, J.; Raho, N.; Zapata, M., Gambierdiscus excentricus sp. nov. (Dinophyceae), a benthic toxic dinoflagellate from the Canary Islands (NE Atlantic Ocean). Harmful Algae 2011, 11, 10-22.

19. Bravo, I.; Rodriguez, F.; Ramilo, I.; Rial, P.; Fraga, S., CiguateraCausing Dinoflagellate Gambierdiscus spp. (Dinophyceae) in a Subtropical Region of North Atlantic Ocean (Canary Islands): Morphological Characterization and Biogeography. Toxins 2019, 11, 423.

20. Rodríguez, F.; Fraga, S.; Ramilo, I.; Rial, P.; Figueroa, R. I.; Riobó, P.; Bravo, I., Canary Islands (NE Atlantic) as a biodiversity 'hotspot' of Gambierdiscus: Implications for future trends of ciguatera in the area. Harmful Algae 2017, 67, 131-143.

21. Perez-Arellano, J.-L.; Luzardo, O. P.; Brito, A. P.; Cabrera, M. H.; Zumbado, M.; Carranza, C.; Angel-Moreno, A.; Dickey, R. W.; Boada, L. D., Ciguatera fish poisoning, Canary Islands. Emerg. Infect. Di. 2005, 11, 1981 .

22. Boada, L. D.; Zumbado, M.; Luzardo, O. P.; Almeida-González, M.; Plakas, S. M.; Granade, H. R.; Abraham, A.; Jester, E. L.; Dickey, R. W., Ciguatera fish poisoning on the West Africa Coast: An emerging risk in the Canary Islands (Spain). Toxicon 2010, 56, 1516-1519.

23. Bravo, J.; Suárez, F.; Ramírez, A.; Acosta, F., Ciguatera, an emerging human poisoning in Europe. J. Aquac. Mar. Biol 2015, 3, 00053.

24. Silva, M.; Rodriguez, I.; Barreiro, A.; Kaufmann, M.; Neto, A.; Hassouani, M.; Sabour, B.; Alfonso, A.; Botana, L.; Vasconcelos, V.,
First report of ciguatoxins in two starfish species: Ophidiaster ophidianus and Marthasterias glacialis. Toxins 2015, 7, 3740-3757.

25. Costa, P.; Estevez, P.; Castro, D.; Soliño, L.; Gouveia, N.; Santos, C.; Rodrigues, S.; Leao, J.; Gago-Martínez, A., New insights into the occurrence and toxin profile of ciguatoxins in Selvagens Islands (Madeira, Portugal). Toxins 2018, 10, 524.

26. Aligizaki, K.; Nikolaidis, G., Morphological identification of two tropical dinoflagellates of the genera Gambierdiscus and Sinophysis in the Mediterranean Sea. J. Biol. Res.-Thessalon. 2008, 9, 75-82.

27. Tudó, À.; Toldrà, A.; Andree, K. B.; Rey, M.; Fernández-Tejedor, M.; Campàs, M.; Diogène, J., First report of Gambierdiscus in the Western Mediterranean Sea (Balearic Islands). Harmful Algae News 2018, 59, 22-23.

28. Laza-Martínez, A.; David, H.; Riobó, P.; Miguel, I.; Orive, E., Characterization of a strain of Fukuyoa paulensis (Dinophyceae) from the Western Mediterranean Sea. J. Eukaryot. Microbiol. 2016, 63, 481497.

29. US FDA (United States Food and Drug Administration), 2011. Fish and Fishery Products Hazards and Controls Guidance, 4th ed., Diane Publishing Co., Philadelphia.

30. FSANZ (Food Standards Australia New Zealand), 2006. A guide to the Australian Primary Production and Processing Standard for Seafood, Safe Seafood Australia, 2nd ed., Canberra.

31. MHWL (Ministry of Health, Welfare, and Labour), 1953. A ban on domestic sales of barracuda. MHWL notification No. 20, June $22^{\text {nd }}$ 1953, Food Sanitation Law (Directorates) 2010, Shin-Nippon-Houki, Japan, 1389.

32. MHWL (Ministry of Health, Welfare, and Labour), 2001., Handling of ciguatera fish, Office memorandum, by MHWL to heads of quarantine stations, January $22^{\text {nd }} 2001$, Food Sanitation Law (Directorates) 2010, Shin-Nippon-Houki, Japan, 202-203.

33. Reverté, L.; Soliño, L.; Carnicer, O.; Diogène, J.; Campàs, M., Alternative methods for the detection of emerging marine toxins: biosensors, biochemical assays and cell-based assays. Mar. Drugs 2014, 12, 5719-5763.

34. Hokama, Y.; Banner, A.; Boylan, D., A radioimmunoassay for the detection of ciguatoxin. Toxicon 1977, 15, 317-325.

35. Hokama, Y., A rapid, simplified enzyme immunoassay stick test for the detection of ciguatoxin and related polyethers from fish tissues. Toxicon 1985, 23, 939-946.

36. Hokama, Y.; Shirai, L.; Iwamoto, L.; Kobayashi, M.; Goto, C.; Nakagawa, L., Assessment of a rapid enzyme immunoassay stick test for the detection of ciguatoxin and related polyether toxins in fish tissues. Biol. Bull. 1987, 172, 144-153.

37. Park, D., Detection of ciguatera and diarrheic shellfish toxins in finfish and shellfish with ciguatect kit. J. AOAC Int. 1995, 78, 533537.

38. Bienfang, P.; DeFelice, S.; Dowling, A., Quantitative evaluation of commercially available test kit for ciguatera in fish. Food Nutr. Sci. 2011, 2, 594.

39. Ebesu, J. S.; Campora, C. E., Comment on "Quantitative evaluation of commercially available test kit for ciguatera in fish". Food Nutr. Sci. 2012, 3, 1233.

40. Dickey, R.; Granade, H.; McClure, F., Evaluation of a solid-phase immunobead assay for detection of ciguatera-related biotoxins in Caribbean finfish. Mem. Queensl. Mus. 1994, 34, 481-488.

41. Bentur, Y.; Spanier, E., Ciguatoxin-like substances in edible fish on the eastern Mediterranean. Clin. Toxicol. 2007, 45, 695-700.

42. Oguri, H.; Hirama, M.; Tsumuraya, T.; Fujii, I.; Maruyama, M.; Uehara, H.; Nagumo, Y., Synthesis-based approach toward direct sandwich immunoassay for ciguatoxin CTX3C. J. Am. Chem. Soc. 2003, 125, 7608-7612.

43. Nagumo, Y.; Oguri, H.; Tsumoto, K.; Shindo, Y.; Hirama, M.; Tsumuraya, T.; Fujii, I.; Tomioka, Y.; Mizugaki, M.; Kumagai, I., Phagedisplay selection of antibodies to the left end of CTX3C using synthetic fragments. J. Immunol. Methods 2004, 289, 137-146.

44. Tsumuraya, T.; Fujii, I.; Hirama, M., Production of monoclonal antibodies for sandwich immunoassay detection of Pacific ciguatoxins. Toxicon 2010, 56, 797-803. 
45. Tsumuraya, T.; Fujii, I.; Hirama, M., Preparation of anti-ciguatoxin monoclonal antibodies using synthetic haptens: sandwich ELISA detection of ciguatoxins. J. AOAC Int. 2014, 97, 373-379.

46. Tsumuraya, T.; Fujii, I.; Inoue, M.; Tatami, A.; Miyazaki, K.; Hirama, M., Production of monoclonal antibodies for sandwich immunoassay detection of ciguatoxin 51-hydroxyCTX3C. Toxicon 2006, 48, 287-294.

47. Tsumuraya, T.; Sato, T.; Hirama, M.; Fujii, I., Highly sensitive and practical fluorescent sandwich ELISA for ciguatoxins. Anal. Chem. 2018, 90, 7318-7324.

48. Tsumuraya, T.; Takeuchi, K.; Yamashita, S.; Fujii, I.; Hirama, M., Development of a monoclonal antibody against the left wing of ciguatoxin CTX1B: Thiol strategy and detection using a sandwich ELISA Toxicon 2012, 60, 348-357.
49. Diogène, J.;Reverté, L., Rambla-Alegre, M.; del Rio, V.; de la Iglesia, P.; Campàs, M.; Palacios, O.; Flores, C.; Caixach, J.; Ralijaona, C.; Razanajatovo, I.; Pirog, A.; Magalon, H.; Arnich, N.; Turquet, J.; Identification of ciguatoxins in a shark involved in a fatal food poisoning in the Indian Ocean. Sci. Rep. 2017, 7, 8240.

50. Soliño, L.; Widgy, S.; Pautonnier, A.; Turquet, J.; Loeffler, C. R.; Quintana, H. A. F.; Diogène, J., Prevalence of ciguatoxins in lionfish (Pterois spp.) from Guadeloupe, Saint Martin, and Saint Barthélmy islands (caribbean). Toxicon 2015, 102, 62-68

51. Manger, R. L.; Leja, L. S.; Lee, S. Y.; Hungerford, J. M.; Wekell, M. M., Tetrazodium-based cell bioassay for neurotoxins active on voltage-sensitive sodium channels: semiautomated assay for saxitoxins, brevetoxins and ciguatoxins. Anal. Biochem. 1993, 214, 190194. 


\section{Addressing the analytical challenges for the detection of ciguatoxins using an electrochemical biosensor}

Sandra Leonardo ${ }^{1}$, Greta Gaiani ${ }^{1}$, Takeshi Tsumuraya ${ }^{2}$, Masahiro Hirama ${ }^{2}$, Jean Turquet $^{3}$, Núria Sagristà $^{1}$, Maria Rambla-Alegre ${ }^{1}$, Cintia Flores ${ }^{4}$, Josep Caixach ${ }^{4}$, Jorge Diogène ${ }^{1}$, Ciara K. O’Sullivan ${ }^{5,6}$, Carles Alcaraz ${ }^{1}$, Mònica Campàs ${ }^{1 *}$

${ }^{1}$ IRTA, Ctra. Poble Nou km 5.5, 43540 Sant Carles de la Ràpita, Spain

${ }^{2}$ Department of Biological Sciences, Graduate School of Science, Osaka Prefecture University, Osaka 599-8570, Japan

${ }^{3}$ Citeb, C/o CYROI, 2 Rue Maxime Rivière, 97490 Sainte Clotilde, La Réunion, France

${ }^{4}$ Mass Spectrometry Laboratory/Organic Pollutants, IDAEA-CSIC, C. Jordi Girona 18, 08034 Barcelona, Spain

${ }^{5}$ Departament d'Enginyeria Química, URV, Av. Països Catalans 26, 43007 Tarragona, Spain

${ }^{6}$ ICREA, Pg. Lluís Companys 23, 08010 Barcelona, Spain

\section{Table of contents}

Figure S1. Conjugation of different $3 \mathrm{G} 8$ capture mAb dilutions to MBs.

Figure S2. Optimisation of the biotinylated $8 \mathrm{H} 4$ detector $\mathrm{mAb}$ dilution.

Figure S3. Optimisation of the polyHRP-streptavidin dilution.

Figure S4. HRMS exact mass spectra of CTX1B standard and extract of $V$. louti.

Table S1. Fish data and CTX1B equivalent contents (pg/g) obtained in the analysis by colorimetric immunoassay and electrochemical biosensor without applying the correction factors. 


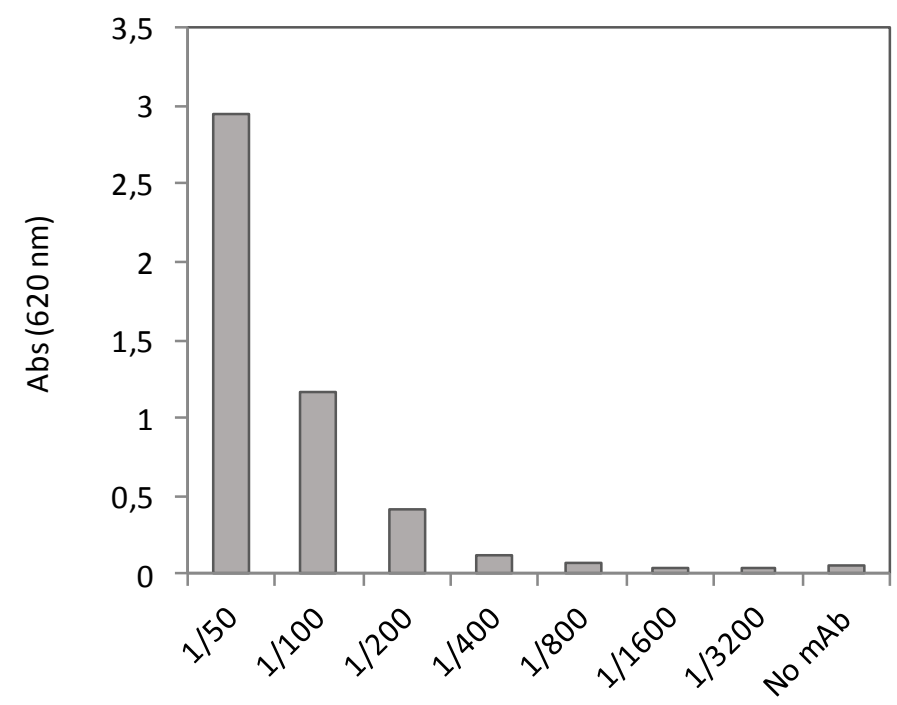

Figure S1. Conjugation of different 3G8 capture mAb dilutions to MBs. Signal is obtained after incubation of $3 \mathrm{G} 8 \mathrm{mAb}-\mathrm{MB}$ conjugates with anti-mouse IgG-HRP and subsequent incubation with TMB.

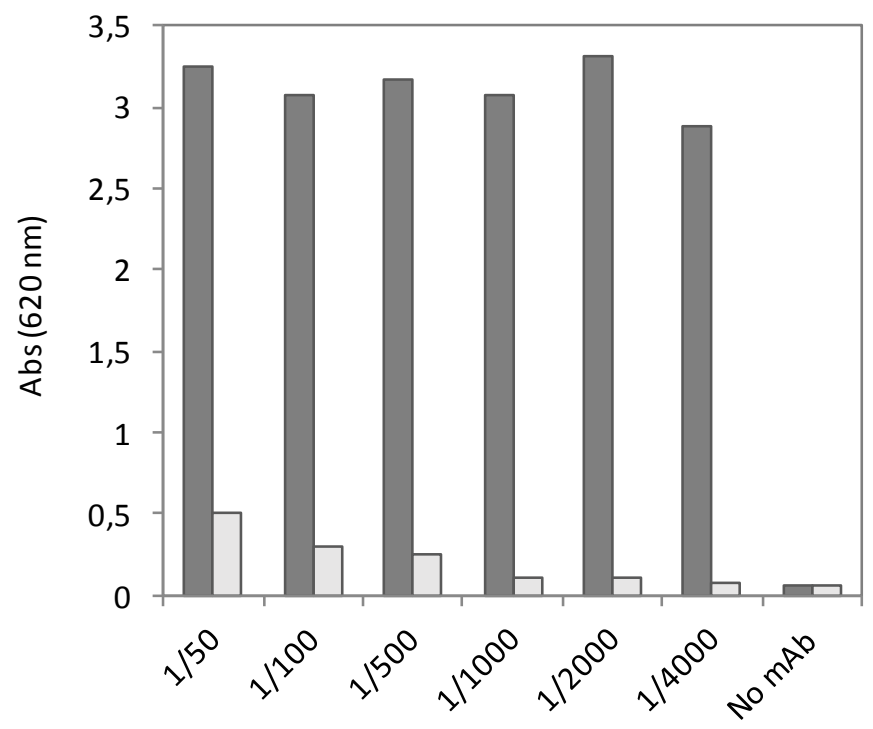

Figure S2. Optimisation of the biotinylated $8 \mathrm{H} 4$ detector mAb dilution. Dark grey bars show absorbance values after the incubation with different biotinylated $8 \mathrm{H} 4 \mathrm{mAb}$ dilutions in the presence of $1000 \mathrm{pg} / \mathrm{mL}$ CTX1B. Light grey bars show absorbance values in the absence of CTX1B. 


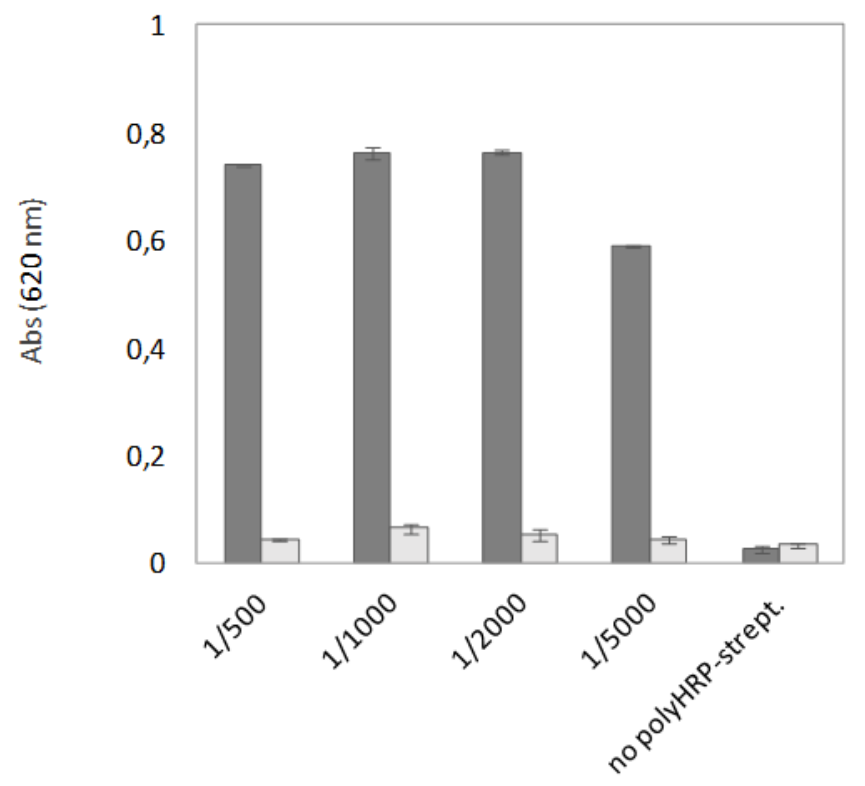

Figure S3. Optimisation of the polyHRP-streptavidin dilution. Dark grey bars show absorbance values after the incubation with different polyHRP-streptavidin dilutions in the presence of $100 \mathrm{pg} / \mathrm{mL}$ CTX1B. Light grey bars show absorbance values in the absence of CTX1B.

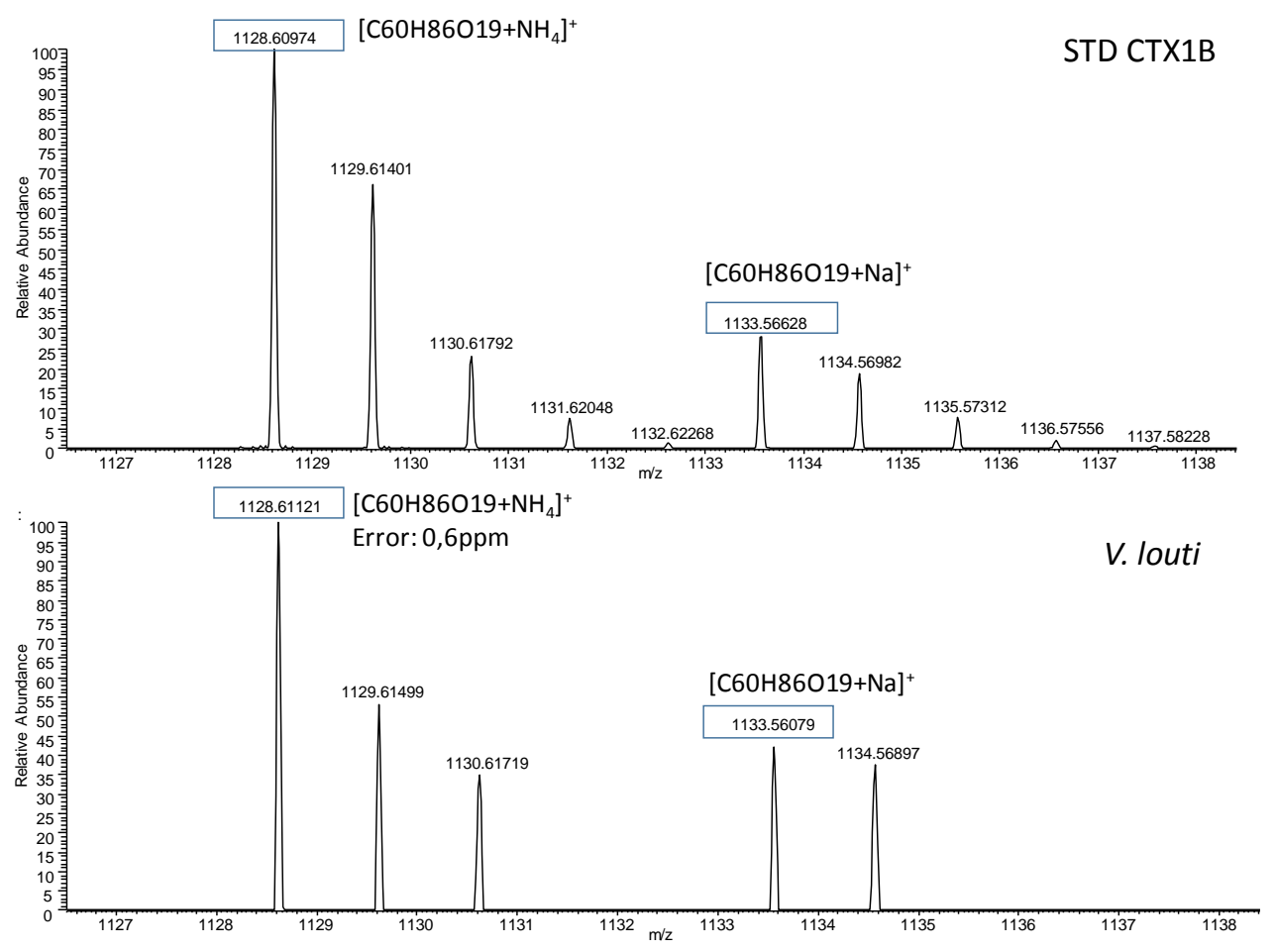

Figure S4. HRMS exact mass spectra of CTX1B standard and extract of $V$. louti.

Table S1. Fish data and CTX1B equivalent contents (pg/g) obtained in the analysis by colorimetric immunoassay and electrochemical biosensor without applying the correction factors. 


\begin{tabular}{|c|c|c|c|c|}
\hline Species & Fishing date & Fishing site & Immunoassay & Immunosensor \\
\hline Variola louti & January 2013 & Saint-Gilles, Réunion & nd & nd \\
\hline Variola louti & March 2013 & Saint-Gilles, Réunion & nd & nd \\
\hline Variola louti & March 2013 & Saint-Gilles, Réunion & nd & nd \\
\hline Variola louti & March 2013 & Saint-Gilles, Réunion & nd & nd \\
\hline Variola louti & April 2013 & Saint-Gilles, Réunion & nd & nd \\
\hline Variola louti & July 2003 & $\begin{array}{l}\text { La Pérouse Seamount, } \\
\text { Réunion }\end{array}$ & $21.57 \pm 1.32$ & $18.79 \pm 1.12$ \\
\hline Variola louti & April 2004 & $\begin{array}{l}\text { La Pérouse Seamount, } \\
\text { Réunion }\end{array}$ & $39.27 \pm 12.00$ & $33.57 \pm 15.40$ \\
\hline Variola louti & January 2003 & $\begin{array}{c}\text { La Pérouse Seamount, } \\
\text { Réunion }\end{array}$ & $94.73 \pm 4.57$ & $80.83 \pm 28.51$ \\
\hline Variola louti†* & March 2015 & Maurice & $246.98 \pm 3.26$ & $205.66 \pm 29.50$ \\
\hline Lutjanus bohar & September 2002 & $\begin{array}{l}\text { La Pérouse Seamount, } \\
\text { Réunion }\end{array}$ & $5.94 \pm 0.33$ & $4.24 \pm 0.37$ \\
\hline Lutjanus bohar & August 2003 & $\begin{array}{c}\text { La Pérouse Seamount, } \\
\text { Réunion }\end{array}$ & $5.83 \pm 0.66$ & $4.45 \pm 0.52$ \\
\hline Lutjanus bohar & August 2003 & $\begin{array}{c}\text { La Pérouse Seamount, } \\
\text { Réunion }\end{array}$ & $14.71 \pm 0.35$ & $10.91 \pm 3.12$ \\
\hline Lutjanus bohar & December 2003 & $\begin{array}{c}\text { La Pérouse Seamount, } \\
\text { Réunion }\end{array}$ & $17.53 \pm 0.59$ & $15.99 \pm 5.07$ \\
\hline Lutjanus bohar & February 2003 & $\begin{array}{l}\text { La Pérouse Seamount, } \\
\text { Réunion }\end{array}$ & $131.94 \pm 7.25$ & $111.74 \pm 27.21$ \\
\hline Lutjanus bohar & January 2002 & $\begin{array}{c}\text { La Pérouse Seamount, } \\
\text { Réunion }\end{array}$ & $125.76 \pm 2.22$ & $122.01 \pm 23.60$ \\
\hline Thyrsitoides marleyi $\dagger$ & June 2015 & Saint-Paul, Réunion & $77.87 \pm 8.39$ & $64.82 \pm 28.30$ \\
\hline
\end{tabular}

